\title{
PERAN GENDER SEBAGAI VARIABEL MODERASI DALAM PENGARUH KEPUASAN PELANGGAN TERHADAP LOYALITAS PELANGGAN
}

\author{
Rizky Aditya Maharany ${ }^{1}$ \\ I Wayan Santika ${ }^{2}$
}

\author{
${ }^{1,2}$ Fakultas Ekonomi dan Bisnis Universitas Udayana (Unud), Bali, Indonesia \\ email: rizkymaharany@gmail.com
}

\begin{abstract}
ABSTRAK
Penelitian ini bertujuan untuk menjelaskan peran gender sebagai variable moderasi dalam pengaruh kepuasan pelanggan terhadap loyalitas pelanggan. Penelitian ini dilakukan di kota Denpasar yang melibatkan 110 responden. Untuk memperoleh data penelitian, digunakan metode dengan menyebar kuesioner. Teknik analisis data yang digunakan dalam penelitian ini adalah analisis regresi moderasi. Hasil penelitian ini menyatakan kepuasan pelanggan berpengaruh secara signifikan terhadap loyalitas pelanggan. Gender memoderasi pengaruh kepuasan pelanggan terhadap loyalitas pelanggan, gender sebagai variabel moderasi yang memperkuat pengaruh kepuasan pelanggan terhadap loyalitas pelanggan. Pihak manajemen diharapkan dapat mempertimbangkan faktor gender, hal itu dikarenakan variabel tersebut dapat dijadikan sebagai indikasi bagaimana tingkat kepuasan pelanggan berbeda jika dilihat dari aspek gender tergantung kebutuhan serta pertimbangan masing - masing individu.

Kata kunci: kepuasan pelanggan, loyalitas pelanggan, gender
\end{abstract}

\section{ABSTRACT}

This study aims to explain gender as a moderating variable in the effect of customer satisfaction on customer loyalty. This research was conducted in the city of Denpasar which involved 110 respondents. To obtain research data, a method was used by distributing questionnaires. The data analysis technique used in this study is moderating regression analysis. The results of this study state that customer satisfaction significantly influences customer loyalty. Gender as a moderating variable in the effect of customer satisfaction on customer loyalty, gender as a moderating variable that strengthens the effect of customer satisfaction on customer loyalty. Management is expected to be able to consider gender factors, this is because these variables can be used as an indication of how different levels of customer satisfaction when viewed from the aspect of gender depending on the needs and considerations of each individual.

Keywords: customer satisfaction, customer loyalty, gender 


\section{PENDAHULUAN}

Dewasa ini di era globalisasi, perkembangan dan pertumbuhan penduduk begitu pesat, banyak perubahan dan kebutuhan masyarakat yang bertambah. Kondisi ini membuat masyarakat harus bisa bekerja dan melakukan segala aktivitas lainnya secara tepat dan efisien. Salah satunya adalah adanya jasa transportasi. Jasa transportasi saat ini merupakan sarana yang sangat penting bagi kehidupan, karena mempermudah masyarakat dalam melakukan aktivitasnya tentunya dengan jasa transportasi yang memadai sebagai alat penunjang atau alat bantu. Banyak jasa transportasi memberikan pelayanan baik, namun dalam memahami kebutuhan dan kepuasan konsumennya masih terbatas. Untuk dapat memenuhi kepuasan dari konsumen itu sendiri, perusahaan dituntut untuk mengikuti perkembangan teknologi.

Kemajuan yang sangat pesat dalam dunia teknologi menuntut para pelaku usaha untuk dapat memahami serta memanfaatkannya dalam kegiatan bisnis sebagai upaya untuk meningkatkan daya saing (Rasyid, 2017). Salah satu hasil kemajuan teknologi yang berkontribusi besar adalah internet. Dengan adanya internet, cara perusahaan melakukan transaksi berubah, dari cara lama yang prosesnya mengorbankan waktu dan biaya yang besar menjadi proses yang lebih cepat dan lebih mudah. Pelaku bisnis sendiri mulai menyadari tren pengguna internet yang terus mengalami peningkatan dapat dijadikan sebagai salah satu peluang bisnis yang menjanjikan. Salah satu perusahaan yang dapat memanfaatkan media internet dalam aktivitas bisnisnya adalah perusahaan penyedia jasa transportasi. Kehadiran jasa transportasi berbasis aplikasi online yang menggunakan internet sangat berpengaruh bagi masyarakat dalam memudahkan masyarakat melakukan kegiatan sehari-hari dengan mengedepankan teknologi yang semakin maju serta mendukung segala aktivitas masyarakat secara cepat dan efisien. Melihat peluang tersebut PT. Go-jek Indonesia memanfaatkannya dengan mengintegrasikan jasa transportasi dan teknologi.

PT. Go-jek Indonesia adalah salah satu perusahaan ojek online yang mengklaim memberikan layanan yang praktis dan cepat. PT. Go-jek Indonesia merupakan pelopor bisnis ojek online yang didirikan oleh Nadiem Makarim pada Tahun 2010 dan mulai beroperasi sejak Tahun 2011 (Pratama, 2015). Ojek online merupakan angkutan umum yang sama dengan ojek pada umumnya, Ojek online menggunakan sepeda motor dan mobil sebagai sarana pengangkutan, namun ojek online dapat dikatakan lebih maju dibandingkan ojek pada umumnya karena telah terintegrasi dengan kemajuan teknologi. Go-jek memanfaatkan aplikasi pada smartphone (telepon genggam) yang memudahkan pengguna jasa untuk memanggil pengemudi ojek. Para konsumen cukup memesan lewat ponsel, mengetahui kisaran tarif yang harus dibayar, dan bisa melacak keberadaan ojek yang dipesan melalui GPS yang ada di aplikasi ataupun menghubunginya langsung. Pembayarannya dilakukan secara tunai dan non tunai dengan sistem kredit yang bisa di top up lewat aplikasi. Go-jek tidak hanya berfungsi sebagai sarana pengangkutan orang atau barang namun juga dapat dimanfaatkan untuk membeli barang bahkan memesan makanan. 
Go-jek sebagai perusahaan jasa transportasi online yang berkembang merambah luas ke kota-kota besar di Indonesia dan menjelma sebagai perusahaan yang menawarkan jasa transportasi online antar penumpang (Hamda, 2017). Untuk saat ini Go-jek telah beroperasi di 50 kota di Indonesia. Go-jek menyediakan banyak pelayanan seperti Go-Ride dan Go-Car untuk layanan transportasi, Go-Box untuk pindahan mengirim barang dengan mobil box dan pickup, Go-Tix yang memberikan layanan beli tiket bioskop, konser musik, atraksi dan event-event lainnya, Go-Med yang menyediakan layanan untuk memenuhi kebutuhan medis masyarakat dari apotek-apotek berlisensi, Go-Food yang merupakan layanan pesan antar makanan online, Go-Mart yang digunakan untuk membelanjakan kebutuhan sehari-hari, Go-Send layanan kurir instan untuk kirim barang dan dokumen, Go-Glam yang menyediakan layanan jasa perawatan kecantikan, Go-Clean yang menyediakan layanan bersih-bersih dan beres-beres rumah, Go-Massage yang menyediakan layanan pijat profesional, Go-Pulsa yang menyediakan pelayanan untuk pembelian pulsa dan paket data dengan menggunakan Go-Pay.

Awal kemunculannya, sangat banyak masyarakat yang menggunakan layanan dari Go-jek. Seiring berjalannya waktu, Go-jek bukanlah satu-satunya perusahaan penyedia jasa transportasi online di Indonesia. Persaingan penyedia jasa transportasi online terlihat dari survei YLKI (Yayasan Lembaga Konsumen Indonesia) yang menyebutkan Go-jek menduduki rating tertinggi dipilih konsumen, sebanyak 72,6 persen, kemudian Grab sebanyak 66, 9 persen, lalu disusul dengan Uber sebanyak 51 persen dan My BlueBird sebanyak 4,4 persen (YLKI, 2017). Go-jek juga berhasil menjadi perusahaan yang menawarkan jasa transportasi yang mendapat Top Brand Award dalam kategorinya. Top Brand Award adalah sebuah penghargaan yang diberikan kepada merek-merek yang meraih predikat Top yaitu maksimal tiga merek teratas pada Top Brand Index dengan persentase minimal 10 persen (Wikipedia, 2018). Top Brand didasarkan atas hasil riset terhadap konsumen Indonesia di 15 kota besar yaitu Jabodetabek, Bandung, Semarang, Jogjakarta, Surabaya, Malang, Medan, Pekanbaru, Palembang, Balikpapan, Samarinda, Banjarmasin, Makassar, Denpasar dan Manado. Top Brand Index (TBI) diukur dengan menggunakan tiga parameter yaitu top of mind awareness (merek pertama yang disebut responden ketika mendengar suatu kategori produk), last used (produk terakhir yang dikonsumsi atau digunakan oleh responden dalam satu siklus pembelian ulang), dan future intention (produk yang ingin dikonsumsi atau digunakan oleh responden di masa mendatang) (Topbrand-award, 2018). Tabel 1. menyajikan TBI (Top Brand Index) untuk kategori jasa transportasi online Tahun 2016, 2017, dan 2018.

Melalui hasil survei yang dimuat oleh Top Brand tersebut dapat dilihat bahwa Data Top Brand Index Tahun 2016 sampai Tahun 2018 menunjukkan bahwa Go-jek menjadi top brand pada kategori jasa transportasi online, namun dilihat dari persentase per tahunnya brand index Go-jek mengalami penurunan di setiap tahunnya, bahkan brand index Go-jek tidak mengalami peningkatan sama sekali. Pesaing terkuatnya yaitu Grab justru memiliki trend brand index yang positif dari Tahun 2016 sampai dengan Tahun 2018. Hal ini menunjukkan bahwa adanya persaingan ketat antara penyedia jasa transportasi online yang berimbas 
pada sikap loyal pengguna transportasi online. Persaingan yang ketat menyebabkan perusahaan harus mampu menyediakan layanan yang sesuai dengan kebutuhan konsumen. Konsumen yang kebutuhannya telah terpenuhi dengan baik akan menunjukkan kepuasannya (Dwipayana \& Sulistyawati, 2018). Untuk mengetahui pelanggan atau konsumen merasa puas setelah menggunakan jasa transportasi online maka dilakukan survei oleh YLKI (Yayasan Lembaga Konsumen Indonesia).

Tabel 1.

Top Brand Index Jasa Transportasi Online

\begin{tabular}{lccccc}
\hline No & Merek & $\begin{array}{c}\text { TBI 2016 } \\
(\mathbf{\%})\end{array}$ & $\begin{array}{c}\text { TBI 2017 } \\
\mathbf{( \% )}\end{array}$ & $\begin{array}{c}\text { TBI 2018 } \\
\mathbf{( \% )}\end{array}$ & Peringkat \\
\hline 1 & Go-jek & 80,0 & 59,2 & 48,0 & TOP \\
2 & Grab & 14,7 & 28,2 & 44,9 & TOP \\
3 & Uber & 1,7 & 8,0 & - & - \\
4 & Blu-jek & 0,7 & 0,3 & - & - \\
\hline
\end{tabular}

Sumber: www.topbrand-award.com, 2018

Survei yang dilakukan YLKI kepada konsumen yang memakai transportasi online dilakukan pada tanggal 5-16 April 2017, 4.668 responden dilibatkan, 55 persen merupakan konsumen laki-laki, dan 45 persen adalah konsumen perempuan. Responden dari survei didominasi usia kerja sehingga diibaratkan bahwa kehadiran dari transportasi online banyak dipergunakan dan dimanfaatkan oleh pengguna yang berusia pada masa produktif. Berdasarkan survei yang dilakukan ditemukan bahwa masih terdapat ketidakpuasaan konsumen setelah menggunakan jasa transportasi online. Berdasarkan hal tersebut ketidakpuasan konsumen ditunjukkan dalam bentuk-bentuk dari kekecewaan serta keluhan dari konsumen pada jasa transportasi berbasis online.

Tabel 2.

Persentase Kekecewaan atau Keluhan Konsumen Terhadap Jasa Transportasi Online

\begin{tabular}{clcc}
\hline No & \multicolumn{1}{c}{ Kekecewaan Konsumen } & Jumlah & \% \\
\hline 1 & Pengemudi meminta di batalkan/cancel & 1041 & 22.3 \\
2 & Sulit mendapatkan pengemudi/driver & 989 & 21.19 \\
3 & Pengemudi membatalkan secara sepihak & 757 & 16.22 \\
4 & Aplikasi map rusak/error & 612 & 13.11 \\
5 & Plat nomor tidak sesuai dengan kendaraan yang dibawa & 563 & 12.06 \\
6 & Pengemudi tidak dating & 296 & 6.34 \\
7 & Kondisi kendaraan kurang baik & 282 & 6.04 \\
8 & Pengemudi tidak jujur kepada konsumen & 235 & 5.03 \\
9 & Pengemudi memulai perjalanan sebelum bertemu dengan & 232 & 4.97 \\
& pelanggan & & \\
10 & Pengemudi ugal-ugalan & 221 & 4.73 \\
11 & Kendaraan bau asap rokok & 215 & 4.61 \\
12 & Pengemudi tidak mau diberi tahu & 135 & 2.89 \\
13 & Pengemudi merokok saat berkendara & 35 & 0.75 \\
\hline
\end{tabular}

Sumber: YLKI (Yayasan Lembaga Konsumen Indonesia), 2017 
Tabel 2. menunjukkan contoh kekecewaan serta keluhan pengguna terhadap jasa transportasi online dipisahkan menjadi tiga jenis, yaitu aplikasi itu sendiri, kendaraan yang digunakan dan pelayanan Go-jek. Banyaknya keluhan konsumen yang terjadi dilapangan menunjukkan bahwa jasa transportasi online tersebut belum memiliki standar terhadap pelayanan minimal yang diukur. Hal ini mengakibatkan perbedaan pengemudi satu sama lain dalam memberikan pelayanan pada konsumen itu sendiri. Penyedia jasa transportasi online belum memiliki suatu mekanisme dalam penanganan suatu pengaduan (complaint handling mechanism), sebagaimana yang diamanatkan pada Undang-Undang No 8 Tahun 1999 tentang Perlindungan Konsumen, jika konsumen memiliki hak untuk didengar keluhannya atas penggunaan barang/jasa (pasal 4).

Selain itu, bentuk kekecewaan atau keluhan konsumen khususnya terhadap Go-jek juga diutarakan melalui akun resmi twitter dari Go-jek (@gojekindonesia) yang langsung dikelola oleh pihak manajemen Go-jek. Data yang diambil dalam kurun waktu 3 bulan terakhir yaitu bulan September - November 2018 dengan berdasarkan keluhan-keluhan yang paling sering diutarakan konsumen terhadap Go-jek. Keluhan-keluhan tersebut disajikan dalam Tabel 3.

Tabel 3.

Keluhan-keluhan Konsumen Terhadap Go-jek

\begin{tabular}{|c|c|c|c|}
\hline \multirow[t]{2}{*}{ No } & \multirow[t]{2}{*}{ Keluhan Konsumen } & \multicolumn{2}{|c|}{ Jumlah (orang) } \\
\hline & & Laki-laki & Perempuan \\
\hline 1 & Aplikasi error/ gangguan & 11 & 19 \\
\hline 2 & Sulit mendapatkan pengemudi & 5 & 4 \\
\hline 3 & Sikap pengemudi Go-jek yang tidak baik & 10 & 12 \\
\hline 4 & Pengemudi berangkat tidak sesuai dengan maps pesanan & 2 & 3 \\
\hline 5 & $\begin{array}{l}\text { Pengemudi melakukan perjalanan sebelum bertemu/menjemput } \\
\text { konsumen }\end{array}$ & 4 & 5 \\
\hline 6 & Pengemudi meminta konsumen membatalkan pesanan & 10 & 16 \\
\hline 7 & $\begin{array}{l}\text { Pengemudi mengambil pesanan namun tidak menjemput dan } \\
\text { saldo Go-Pay terpotong }\end{array}$ & 3 & 8 \\
\hline 8 & $\begin{array}{l}\text { Pengemudi tidak memberikan rasa aman dan nyaman kepada } \\
\text { konsumen }\end{array}$ & 10 & 12 \\
\hline 9 & Paket yang sudah dikirim tidak sampai ke konsumen & 5 & 8 \\
\hline 10 & Kondisi kendaraan kurang baik & 1 & 2 \\
\hline 11 & $\begin{array}{l}\text { Tidak adanya jaminan tindak kriminal dan kehandalan } \\
\text { pengemudi dalam membawa kendaraan }\end{array}$ & 3 & 3 \\
\hline 12 & Penipuan pada konsumen yang mengatasnamakan Go-jek & 7 & 9 \\
\hline 13 & $\begin{array}{l}\text { Layanan call centre tidak merespon dan memberikan solusi } \\
\text { yang sesuai }\end{array}$ & 6 & 8 \\
\hline 14 & Waktu penjemputan yang lebih lama & 8 & 9 \\
\hline 15 & $\begin{array}{l}\text { Biaya pengiriman berubah tidak sesuai dengan biaya yang } \\
\text { tertera pada awal pemesanan }\end{array}$ & 5 & 5 \\
\hline & Total & 90 & 123 \\
\hline
\end{tabular}

Sumber: Akun resmi twitter dari Go-jek (@gojekindonesia), 2018

Tabel 3. menunjukkan keluhan - keluhan yang diberikan oleh konsumen terhadap Go-jek. Jumlah konsumen yang melakukan keluhan terhadap Go-jek adalah sebanyak 213 orang. Pengguna jasa Go-jek dengan jenis kelamin perempuan mendominasi keluhan-keluhan yang dituangkan dalam akun resmi twitter dari Go-jek dengan jumlah sebesar 123 orang, dan pengguna laki-laki 
dengan jumlah sebesar 90 orang. Berdasarkan hal tersebut terlihat adanya perbedaan ketidakpuasan antara laki-laki dengan perempuan terhadap jasa Go-jek. Ketidakpuasan serta penilaian negatif dari pelanggan akan berdampak pada sikap loyal pelanggannya. Kondisi ini mengakibatkan pelanggan dihadapkan pada berbagai pilihan jasa dengan harga, kualitas yang bervariasi serta kebutuhan dan keinginan yang tak terbatas, kemudian pelanggan senantiasa akan mencari nilai tertinggi dari jasa-jasa tersebut dan tentunya dapat membuat pelanggan merasa puas dan loyal (Masitha \& Suprihhadi, 2014).

Loyalitas secara harfiah didefinisikan sebagai kesetiaan, yaitu kesetiaan seseorang pada suatu objek (Razak et al., 2016). Loyalitas pelanggan merupakan sikap menyenangi terhadap suatu merek yang direpresentasikan dalam pembelian yang konsisten terhadap merek sepanjang waktu dengan nilai yang dirasakan pada suatu produk (Shahroudi \& Naimi, 2015). Loyalitas pelanggan adalah suatu komitmen yang kuat dari pelanggan, sehingga bersedia melakukan pembelian ulang terhadap produk atau jasa yang disukai secara konsisten dalam jangka panjang, tanpa terpengaruh oleh situasi dan usaha-usaha pemasaran dari produk lain yang berusaha membuat mereka beralih untuk membeli produk lain (Griffin, 2005:31). Keberhasilan sebuah perusahaan dalam membangun loyalitas pada umumnya dipengaruhi oleh kepuasan pelanggannya (Supar \& Suasana, 2017). Untuk memperoleh loyalitas pelanggan, perusahaan harus memperhatikan kepuasan pelanggan (Tjahjaningsih \& Yuliani, 2009).

Kepuasan adalah keseluruhan tingkat kesenangan dan kepuasan konsumen yang di harapkan dari pengalaman dengan pelayanan (Ha \& Jang, 2010). Kepuasan pelanggan yaitu bagaimana konsumen merasa puas, yang dimana konsumen merasa puas yang dimaksud adalah telah terpenuhinya atau terlampaui dari pengharapannya (Fata, 2015). Kepuasan pelanggan ialah kunci dalam menghadirkan loyalitas pelanggan itu sendiri (Chang \& Fong, 2010). Kepuasan pelanggan sangat erat hubungannya dengan loyalitas pelanggan, dimana pelanggan yang terpuaskan akan menjadi pelanggan yang loyal (Prasada \& Ekawati, 2018). Apabila pelanggan mendapat apa yang diinginkan setelah memakai produk atau jasa yang ditawarkan, kemudia setelah mereka memakai produk atau jasa itu mereka mendapat suatu pengalaman yang kemudian mendorong mereka agar melakukan pembelian kembali, sehingga menimbulkan rasa loyal terhadap produk atau jasa itu. Pelanggan yang merasa puas akan suatu produk akan melakukan pembelian kembali akan produk itu (Kitapci, Dortyol, Yaman, \& Gulmez, 2013). Kepuasan konsumen merupakan konsep kunci dibidang pemasaran dan manajemen, terutama di industri jasa Heung \& Tianming (2012), dengan memertahankan dan memuaskan pelanggan saat ini jauh lebih mudah dibandingkan terus-menerus berupaya menarik atau mencari pelanggan baru, biaya memertahankan pelanggan lebih rendah dibandingkan biaya mencari pelanggan baru (Buttle, 2017:28).

Penelitian sebelumnya mengenai pengaruh kepuasan pelanggan terhadap loyalitas pelanggan telah banyak dilakukan. Penelitian yang dilakukan Lee (2013), Tjahjaningsih \& Yuliani (2009) dan Wardhana (2016) menyimpulkan bahwa kepuasan berpengaruh positif dan signifikan dalam mempengaruhi loyalitas pelanggan. Liu et al. (2012) dalam penelitiannya menyatakan kepuasan pelanggan 
yang tinggi dapat meningkatkan loyalitas dari pelanggan. Namun berbeda dari penelitian sebelumnya, penelitian yang dilakukan oleh Yaqin \& Ilfitriah (2014) menyimpulkan bahwa kepuasan berpengaruh positif dan tidak signifikan terhadap loyalitas pelanggan.

Kepuasan dari pelanggan perempuan atau laki-laki di dalam menggapai loyalitas pelanggan mempunyai suatu perbedaan dikarenakan satu sama lain pelanggan mempunyai suatu sudut pandang yang berbeda, alhasil mempengaruhi perilaku serta tanggapan yang tak sama akan suatu produk. Perbedaan fisik dan psikologis mereka melahirkan perbedaan kebutuhan, harapan, keinginan, gaya hidup, lingkungan sosial, dan pola konsumsi. Walaupun perbedaan tersebut tidak seratus persen, tetapi perbedaan tersebut ada. Laki-laki dan perempuan mungkin memiliki keinginan yang sama, tetapi kekuatan keinginan tersebut mungkin saja berbeda. Kotler \& Kervin (2009:237) menyembutkan, kebutuhan serta keinginan pelanggan memiliki hubungan yang erat terhadap jenis kelamin atau gender. Foroughi et al. (2013) mengemukakan jenis kelamin (gender) adalah perbedaan sosial masyarakat antara laki-laki dan peran perempuan, peran dan cara orang dalam masyarakat sosial memandang seorang laki-laki dan seorang perempuan.

Penelitian Ma et al. (2015) menyatakan bahwa pelanggan perempuan menunjukkan tingkat kepuasan yang lebih tinggi daripada pelanggan laki-laki. Dong et al. (2011) dalam penelitiannya menemukan bahwa wanita memiliki efek signifikan pada pengaruh kepuasan terhadap loyalitas, dalam artian bahwa wanita lebih loyal daripada laki-laki. Namun berbeda dengan penelitian sebelumnya, dalam temuan Okoroafo et al. (2010) menunjukkan tidak ada perbedaan gender dalam mempersepsikan rangsangan pemasaran perusahaan sehingga belum dapat dipastikan ini akan berdampak pada kepuasan dan loyalitas pelanggan. Menurut Qayyum et al. (2013) menyimpulkan bahwa gender tidak memiliki peran moderasi pada kepuasan terhadap loyalitas pelanggan.

Tujuan yang ingin dicapai dari penelitian ini adalah mengkaji pengaruh kepuasan pelanggan terhadap loyalitas pelanggan. Mengkaji peran gender dalam memoderasi pengaruh kepuasan pelanggan terhadap lotalitas pelanggan. Hasil penelitian ini diharapkan dapat memberikan manfaat untuk dapat digunakan sebagai sarana untuk melatih berpikir ilmiah, dengan berdasar pada disiplin ilmu yang diperoleh di bangku kuliah. Penelitian ini juga diharapkan dapat menambah pengetahuan tentang kepuasan pelanggan, gender serta loyalitas pelanggan dan dapat memberikan gambaran kepada peneliti selanjutnya mengenai pengaruh kepuasan pelanggan terhadap loyalitas pelanggan dengan gender sebagai variabel moderasi. Diharapkan dapat bermanfaat bagi pihak perusahaan, yaitu sebagai masukan dan pertimbangan dalam mengembangkan dan menyempurnakan kebijakan perusahaan, khususnya yang berhubungan dengan kepuasan pelanggan, gender dan loyalitas pelanggan.

Menurut (Kotler \& Kervin, 2009:166) perilaku kosumen adalah studi tentang bagaimana individu, kelompok dan organisasi memilih, membeli, menggunakan dan bagaimana barang, jasa, ide atau pengalaman untuk memuaskan kebutuhan dan keinginan mereka. Loyalitas pelanggan adalah suatu komitmen yang kuat dari pelanggan, sehingga bersedia melakukan pembelian ulang terhadap produk atau jasa yang disukai secara konsisten dalam jangka 
panjang, tanpa terpengaruh oleh situasi dan usaha-usaha pemasaran dari produk lain yang berusaha membuat mereka beralih untuk membeli produk lain (Griffin, 2005:31). Menurut (Kotler \& Kervin, 2009:35) kepuasan adalah perasaan senang atau kecewa seseorang yang berasal dari perbandingan antara kesannya terhadap kinerja atau hasil suatu produk atau jasa dan harapan-harapannya. Foroughi et al. (2013) mengemukakan jenis kelamin (gender) adalah perbedaan sosial masyarakat antara laki-laki dan peran perempuan, peran dan cara orang dalam masyarakat sosial memandang seorang laki-laki dan seorang perempuan. Gender membedakan setiap individu penduduk dengan jenis kelamin laki-laki dan jenis kelamin perempuan.

Kepuasan pelanggan adalah suatu keadaan dimana keinginan, harapan dan kebutuhan pelanggan terpenuhi. Terciptanya kepuasan konsumen yang optimal maka akan mendorong terciptanya loyalitas dibenak konsumen yang merasa puas. Pengaruh kepuasan seorang pelanggan terhadap loyalitas pelanggan yang dikemukakan oleh Jahanshahi et al. (2011) menyatakan bahwa kepuasan pelanggan berpengaruh positif dan signifikan terhadap loyalitas pelanggan. Sejalan dengan penelitian sebelumnya, Anggarayana \& Pramudana (2013) menyimpulkan bahwa kepuasan pelanggan berpengaruh positif dan signifikan terhadap loyalitas pelanggan di UD. Dewa Putu Toris Gianyar. Sejalan dengan penelitian sebelumnya menurut Cahyana \& Sukaatmadja (2017) kepuasan pelanggan berpengaruh positif dan signifikan terhadap loyalitas pelanggan. Berdasarkan hasil empiris pada penelitian sebelumnya, hipotesis yang dapat diajukan dalam penelitian ini adalah:

$\mathrm{H}_{1}$ : Kepuasan pelanggan berpengaruh positif dan signifikan terhadap loyalitas pelanggan

Penelitian dari Arwani et al. (2011) menyimpulkan jika sebab terjadinya suatu perbedaan hasil dari pengaruh diantara kepuasan pelanggan serta loyalitas pelanggan disebabkan oleh suatu perbedaan karakteristik dari pelanggan dan mencakup pengetahuan, usia, dan jenis kelamin (gender). Menurut Kotler \& Kervin, 2009:237), kebutuhan serta keinginan dari pelanggan memiliki suatu kaitan dengan jenis kelamin ataupun gender. Perempuan diketahui umumnya menempatkan nilai yang lebih tinggi pada hubungan jangka panjang dan memiliki orientasi perasaan yang lebih, yaitu mereka membuat keputusan berdasarkan nilai - nilai sosial dan dengan memperhatikan dampak keputusan mereka terhadap orang lain. Jadi perempuan lebih banyak dan lebih kuat hubungan interpersonal terhadap merek dari laki - laki, hal ini menunjukkan bahwa perempuan lebih setia dibanding laki-laki. Dong et al. (2011) dalam penelitiannya menemukan bahwa wanita memiliki pengaruh positif dan signifikan pada pengaruh kepuasan terhadap loyalitas. Hasil dari penelitian yang dikemukakan oleh (Dhinata \& Kusumadewi, 2014), disimpulkan jika gender secara signifikan dan positif memoderasi pengaruh dari kepuasan pelanggan terhadap loyalitas pelanggan. Berdasarkan hasil empiris pada penelitian sebelumnya, hipotesis yang dapat diajukan dalam penelitian ini adalah: 
$\mathrm{H}_{2}$ : Gender memoderasi pengaruh kepuasan pelanggan terhadap loyalitas pelanggan.

\section{METODE PENELITIAN}

Penelitian ini termasuk jenis penelitian menggunakan pendekatan kuantitatif yang bersifat asosiatif, membahas mengenai pengaruh kepuasan pelanggan terhadap loyalitas pelanggan dengan gender sebagai variabel moderasi. Lokasi Penelitian ini adalah Kota Denpasar. Adapun obyek penelitian ini adalah pengguna Go-jek di Kota Denpasar. Variabel yang diteliti dalam penelitian ini adalah variabel terikat/dependen yaitu loyalitas pelanggan (Y), variabel bebas/independen yaitu kepuasan pelanggan (X), dan varibel moderasi yaiut gender $(\mathrm{Z})$.

Tabel 4.

Indikator Penelitian

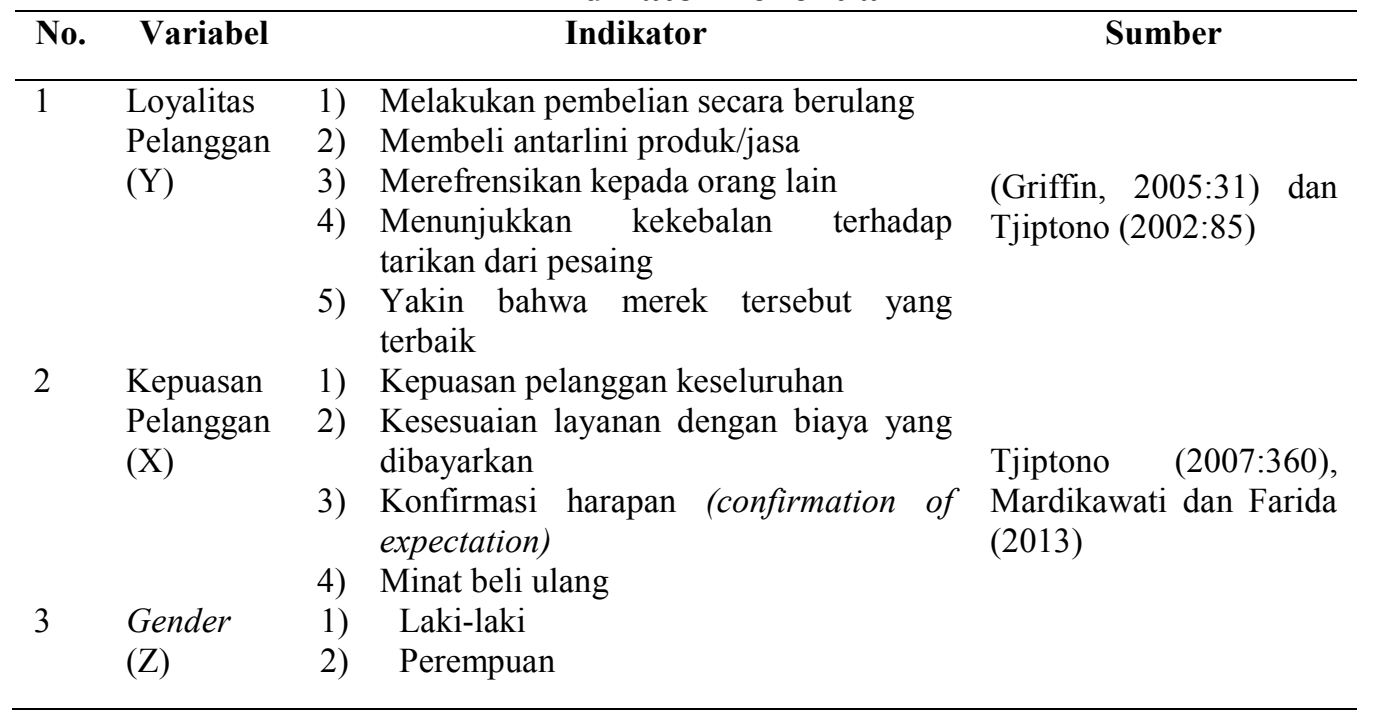

Sumber: Penelitian Sebelumnya, 2018

Populasi dari penelitian ini yaitu konsumen yang memakai jasa Go-jek di Kota Denpasar. Kemudian penelitan ini menggunakan 110 responden dari Kota Denpasar. Pengambilan sampel dalam penelitian ini dilakukan secara non probability sampling, yaitu dengan menggunakan teknik purposive sampling. Metode pengumpulan data menggunakan wawancara dengan menyebar kuesioner. Kuesioner terdiri dari pertanyaan terbuka tentang identitas responden dan pernyataan yang merupakan indikator - indikator dari variabel penelitian.

Uji validitas bertujuan memeriksa apakah kuesioner sebagai instrumen penelitian sudah tepat untuk mengukur apa yang seharusnya diukur (Sugiyono, 2014:172). Suatu instrument dikatakan valid jika nilai koefisisen korelasi r-hitung lebih besar dari 0,30 (Sugiyono, 2014:178). Menurut (Sugiyono, 2014:173), uji reliabilitas adalah suatu pengujian untuk mengetahui sejauh mana hasil suatu pengukuran tetap konsisten apabila dilakukan pengukuran lebih dari satu terhadap gejala yang sama dengan menggunakan alat ukur yang sama. Menurut (Sugiyono, 
2014:184) nilai Alpha Cronbach dikatakan reliabel bila nilainya lebih besar atau sama dengan 0,60 .

Dalam penelitian ini analisis deskriptif digunakan untuk mendeskripsikam objek yang diteliti melalui data sampel atau populasi sebagaimana adanya, tanpa melakukan analisis dan membuat kesimpulan yang berlaku untuk umum. Teknik Statistik Inferensial adalah teknik statistik yang digunakan untuk menganalisis data sampel dan hasilnya diberlakukan untuk populasi. Uji asumsi klasik diperlukan untuk menjadikan model regresi sebagai alat estimasi yang tidak bias. Uji Normalitas bertujuan untuk menguji apakah dalam model regresi, variabel pengganggu atau residual memiliki distribusi normal atau tidak. Model regresi yang baik adalah memiliki distribusi normal atau mendekati normal (Ghozali, 2016:116). Jika asymp.sig (2-tailed) lebih besar dari level of significant yaitu 0,05, maka dapat disimpulkan berdistribusi normal. Uji heterokedasitas bertujuan untuk menguji apakah dalam sebuah model regresi terjadi ketidaksamaan varians dari residual satu pengamatan ke pengamatan yang lain. Model regresi yang baik adalah yang homoskedastisitas atau tidak terjadi heteroskedastisitas (Ghozali, 2016:134). Jika signifikansi nya lebih besar dari 0,05 maka varian tidak terdapat heterokedasitas.

Teknik analisis data yang digunakan untuk menguji hipotesis yang diajukan dalam penelitian ini adalah dengan menggunakan analisis regresi moderasi (Moderated Regression Analysis). Bentuk regresi ini dirancang untuk menentukan hubungan antar dua variabel yang dipengaruhi oleh variabel ketiga (variabel moderasi). Adapun rumus persamaan Moderated Regression Analysis (MRA) yang digunakan adalah sebagai berikut:

$$
\mathrm{L}=\alpha+\beta_{1}(\mathrm{~K})+\beta_{2}(\mathrm{G})+\beta_{3}(\mathrm{~K} . \mathrm{G})+e .
$$

Keterangan:

$$
\begin{array}{ll}
\mathrm{Y} & : \text { Loyalitas Pelanggan } \\
\alpha & : \text { Konstanta } \\
\beta_{1}-\beta_{3} & : \text { Koefisien regresi } \\
\mathrm{X} & : \text { Kepuasan Pelanggan } \\
\mathrm{Z} & : \text { Gender } \\
\mathrm{X} . \mathrm{Z} & : \text { Interaksi antara Kepuasan Pelanggandengan Gender } \\
e & : \text { Error }
\end{array}
$$

Kelayakan Model (Uji F) yang memperlihatkan jika model ataupun persamaan regresi yang sudah di buat layak diteliti. Kelayakan dari suatu model dapat dilihat melalui nilai probabilitas signifikansinya, adalah jika nilai probabilitas signifikansi lebih kecil terhadap tingkat signifikansi $\alpha=0,05$ (sig. $<$ 0,05), maka $\mathrm{H}_{0}$ ditolak dan $\mathrm{H}_{1}$ diterima, hal ini berarti variabel independen mempunyai pengaruh signifikan kepada variabel dependen dan diputuskan model regresi yang telah dirumuskan layak di pergunakan dalam penelitian. Jika nilai probabilitas signifikansi lebih besar dari tingkat signifikansi $\alpha=0,05$ (sig. $>0,05)$, maka $\mathrm{H}_{0}$ diterima dan $\mathrm{H}_{1}$ ditolak yang berarti variabel dependen tidak berpengaruh signifikan terhadap variabel idependen sehingga model regresi yang dirumuskan tidak layak untuk digunakan dalam penelitian. 
Koefisien determinasi $\left(\mathrm{R}^{2}\right)$ digunakan untuk mengukur seberapa jauh kemampuan model dalam menjelaskan variabel-variabel dependen. Nilai koefisien determinasi adalah antara nol sampai satu $\left(0<\mathrm{R}^{2}<1\right)$. Uji t digunakan untuk mengetahui jikalau suatu variabel bebas secara individu dapat mempengaruhi variabel terikatnya (Wirawan, 2014:264).

\section{HASIL DAN PEMBAHASAN}

Responden yang digunakan dalam penelitian ini berjumlah 110 responden yang meliputi empat aspek karakteristik, yaitu jenis kelamin, usia, pendidikan terakhir, pekerjaan.

Tabel 5.

Karakteristik Responden

\begin{tabular}{ccccc}
\hline No & Variabel & Klasifikasi & Jumlah Orang & Persentase (\%) \\
\hline 1 & Jenis Kelamin & Laki-laki & 55 & 50 \\
& & Perempuan & 55 & 50 \\
2 & Total & $\mathbf{1 1 0}$ & $\mathbf{1 0 0}$ \\
& & $17-20$ & 34 & 31 \\
& Usia & $21-30$ & 65 & 59 \\
& & Jumlah & 11 & 10 \\
3 & Pendidikan & SMA/SMK & $\mathbf{1 1 0}$ & $\mathbf{1 0 0}$ \\
& Terakhir & Diploma & 60 & 55 \\
& & Sarjana & 6 & 5 \\
& & Jumlah & 44 & 40 \\
4 & Pekerjaan & Pelajar/Mahasiswa & $\mathbf{1 1 0}$ & $\mathbf{1 0 0}$ \\
& & Karyawan Swasta/Wirausaha & 68 & 62 \\
& & Pegawai Negeri Sipil & 33 & 30 \\
& & Jumlah & $\mathbf{1 1 0}$ & 8 \\
& & & $\mathbf{1 0 0}$
\end{tabular}

Sumber: Data diolah, 2018

Tabel 5. menunjukkan karakteristik responden yang terdiri dari jenis kelamin, usia, pendidikan terakhir, dan pekerjaan. Berdasarkan jenis kelamin, responden laki-laki sebanyak 50 persen dan responden perempuan sebanyak 50 persen. Berdasarkan usia diperoleh bahwa responden yang paling banyak yaitu berusia 21-30 tahun yaitu sebesar 59 persen, berusia 17-20 tahun yaitu sebesar 31 persen dan yang berusia $>30$ tahun yaitu sebesar 10 persen. Berdasarkan pendidikan terakhir dapat dilihat bahwa responden dengan pendidikan terakhir SMA/SMK memperoleh persentase tertinggi yaitu sebanyak 55 persen, responden dengan pendidikan terakhir diploma sebanyak 5 persen dan responden dengan pendidikan terakhir sarjana sebanyak 40 persen. Berdasarkan pekerjaan dapat dilihat bahwa responden sebagai pelajar atau mahasiswa memperoleh persentase tertinggi yaitu sebanyak 62 persen, responden dengan pekerjaan sebagai karyawan swasta/wirausaha sebanyak 30 persen, responden sebagai pegawai negeri sipil sebanyak 8 persen.

Hasil dari uji validitas dilihat pada Tabel 6. dibawah memperlihatkan jika indikator penelitian yang dipakai untuk mengukur variabel kepuasan pelanggan, dan loyalitas pelanggan mempunyai nilai koefisien korelasi dengan skor total 
semua butir pernyataan lebih besar dari 0,30 dengan signifikansi kurang dari 0,05. Hal ini memperlihatkan jika butir-butir pernyataan di dalam instrumen penelitian tersebut valid, sehingga layak digunakan.

Tabel 6.

Hasil Uji Validitas

\begin{tabular}{ccccc}
\hline Variabel & Indikator & Koefisien Korelasi & Sig. (2-tailed) & Keterangan \\
\hline \multirow{3}{*}{ Kepuasan pelanggan } & $\mathrm{X}_{1}$ & 0,794 & 0,000 & Valid \\
$\left(\mathrm{X}_{1}\right)$ & $\mathrm{X}_{2}$ & 0,835 & 0,000 & Valid \\
& $\mathrm{X}_{3}$ & 0,812 & 0,000 & Valid \\
& $\mathrm{X}_{4}$ & 0,779 & 0,000 & Valid \\
& $\mathrm{Y}_{1}$ & 0,696 & 0,000 & Valid \\
Loyalitas pelanggan & $\mathrm{Y}_{2}$ & 0,822 & 0,000 & Valid \\
$(\mathrm{Y})$ & $\mathrm{Y}_{3}$ & 0,755 & 0,000 & Valid \\
& $\mathrm{Y}_{4}$ & 0,791 & 0,000 & Valid \\
& $\mathrm{Y}_{5}$ & 0,740 & 0,000 & Valid \\
\hline
\end{tabular}

Sumber: Data diolah, 2018

Tabel 7.

Hasil Uji Reliabilitas

\begin{tabular}{cccc}
\hline No. & Variabel & Cronbach's $\boldsymbol{A l p h a}$ & Keterangan \\
\hline $\mathbf{1}$ & Kepuasan pelanggan $(\mathrm{X})$ & 0,817 & Reliabel \\
$\mathbf{2}$ & Loyalitas pelanggan $(\mathrm{Y})$ & 0,796 & Reliabel \\
\hline
\end{tabular}

Sumber: Data diolah, 2018

Hasil dari uji reliabilitas yang diperlihatkan pada Tabel 7. menunjukkan jika variabel penelitian mempunyai koefisien Cronbach's Alpha lebih dari 0,60. Jadi dapat disimpulkan jika kesemua variabel telah memenuhi syarat reliabilitas serta kehandalan sehingga dapat dipergunakan dan dianalisis lebih lanjut.

Tabel 8. dibawah menunjukkan bahwa variabel loyalitas pelanggan mendapatkan rata-rata skor 3,80 dimana skor tersebut masuk dalam kategori setuju. Rata-rata jawaban tertinggi konsumen terdapat pada pernyataan "Saya mereferensikan layanan Go-jek kepada orang lain" dengan nilai skor rata-rata 3,98. Pernyataan tersebut memperlihatkan sebanyak 1 orang menjawab sangat tidak setuju, 5 orang menjawab tidak setuju, 20 orang menjawab cukup setuju, 53 orang menjawab setuju dan 31 orang menjawab sangat setuju. Nilai skor paling rendah ditunjukkan pada pernyataan "Saya tetap menggunakan layanan jasa Gojek sekalipun tersedia banyak layanan dari jasa transportasi online lainnya dan skor paling rendah juga ditunjukkan pada pernyataan "Saya yakin bahwa Go-jek adalah penyedia jasa transportasi online yang terbaik" dengan skor rata-rata sama yaitu 3,67. Pernyataan "Saya tetap menggunakan layanan jasa Go-jek sekalipun tersedia banyak layanan dari jasa transportasi online lainnya" memperlihatkan sebanyak 1 orang menjawab sangat tidak setuju, 4 orang menjawab tidak setuju, 42 orang menjawab cukup setuju, 46 orang menjawab setuju dan 17 orang menjawab sangat setuju. Pernyataan "Saya yakin bahwa Go-jek adalah penyedia jasa trasportasi online yang terbaik" memperlihatkan sebanyak 4 orang menjawab tidak setuju, 46 orang menjawab cukup setuju, 42 orang menjawab setuju dan 18 orang menjawab sangat setuju. 
Tabel 8.

Penilaian Responden Terhadap Variabel Loyalitas Pelanggan

\begin{tabular}{|c|c|c|c|c|c|c|c|c|}
\hline \multirow[t]{2}{*}{ No } & \multirow[t]{2}{*}{ Pernyataan } & \multicolumn{5}{|c|}{ Jawaban } & \multirow{2}{*}{$\begin{array}{c}\text { Rata- } \\
\text { rata }\end{array}$} & \multirow[t]{2}{*}{ Kriteria } \\
\hline & & STS & TS & CS & $\mathbf{S}$ & SS & & \\
\hline 1 & $\begin{array}{l}\text { Saya menggunakan jasa Go- } \\
\text { jek secara berulang }\end{array}$ & 0 & 5 & 22 & 55 & 28 & 3,96 & Baik \\
\hline 2 & $\begin{array}{l}\text { Saya menggunakan tidak } \\
\text { hanya satu jenis jasa dari } \\
\text { Go-jek, tetapi saya juga } \\
\text { menggunakan berbagai jenis } \\
\text { jasa dari Go-jek }\end{array}$ & 1 & 2 & 44 & 39 & 24 & 3,75 & Baik \\
\hline 3 & 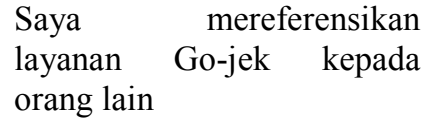 & 1 & 5 & 20 & 53 & 31 & 3,98 & Baik \\
\hline 4 & $\begin{array}{l}\text { Saya tetap menggunakan } \\
\text { layanan jasa } r \text { Go-jek } \\
\text { sekalipun tersedia banyak } \\
\text { layanan dari jasa transportasi } \\
\text { online lainnya }\end{array}$ & 1 & 4 & 42 & 46 & 17 & 3,67 & Baik \\
\hline 5 & 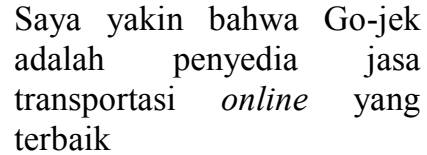 & 0 & 4 & 46 & 42 & 18 & 3,67 & Baik \\
\hline \multicolumn{7}{|c|}{ Total } & $\mathbf{3 , 8 0}$ & Baik \\
\hline
\end{tabular}

Sumber: Data diolah, 2018

Tabel 9. menunjukkan bahwa variabel kepuasan pelanggan mendapatkan rata-rata skor 3,98 dimana skor tersebut masuk dalam kategori setuju. Rata-rata jawaban tertinggi konsumen terdapat pada pernyataan "Saya berminat untuk menggunakan kembali jasa Go-jek" dengan nilai skor rata-rata 4,11. Pernyataan tersebut memperlihatkan sebanyak 3 orang menjawab tidak setuju, 18 orang menjawab cukup setuju, 52 orang menjawab setuju dan 37 orang menjawab sangat setuju. Nilai skor paling rendah ditunjukkan pada pernyataan "Saya merasa puas secara keseluruhan terhadap jasa yang ditawarkan dan diberikan oleh Go-jek dibandingkan dengan penyedia jasa transportasi online lainnya" dengan skor ratarata 3,86. Pernyataan tersebut memperlihatkan sebanyak 1 orang menjawab sangat tidak setuju, 1 orang juga menjawab tidak setuju, 35 orang menjawab cukup setuju, 48 orang menjawab setuju dan 25 orang menjawab sangat setuju. Berikut disajikan dalam Tabel 9.

Dasar pengambilan keputusan dari uji normalitas ini adalah dengan melihat probability asymp.sig (2-tailed). Pada Tabel 10. di bawah menunjukkan hasil uji normalitas dengan uji Kolmogorov-Smirnov, analisis regresi moderasi memperlihatkan nilai Asymp. Sig (2-tailed) 0,326 lebih besar terhadap level of significant, ialah 5 persen $(\alpha=0,05)$, sehingga data yang diuji menyebar normal atau berdistribusi normal.

Tabel 11. menunjukkan bahwa nilai signifikansi kepuasan pelanggan (X) sebesar 0,164, gender $(Z)$ sebesar 0,236, dan interaksi antara kepuasan pelanggan dengan gender (X.Z) sebesar 0,208. Hasil uji tersebut memiliki nilai 
signifikansinya yang lebih besar dari $(\alpha) 0,05$. Oleh karena itu, dapat disimpulkan bahwa tidak terjadi heteroskedastisitas.

Tabel 9.

Penilaian Responden Terhadap Variabel Kepuasan Pelanggan

\begin{tabular}{|c|c|c|c|c|c|c|c|}
\hline \multirow[t]{2}{*}{ No } & \multirow[t]{2}{*}{ Pernyataan } & \multicolumn{5}{|c|}{ Jawaban } & \multirow{2}{*}{$\begin{array}{c}\text { Rata- } \\
\text { rata }\end{array}$} \\
\hline & & STS & TS & CS & $\mathbf{S}$ & SS & \\
\hline 1 & $\begin{array}{l}\text { Saya merasa puas secara keseluruhan } \\
\text { terhadap jasa yang ditawarkan dan } \\
\text { diberikan oleh Go-jek dibandingkan } \\
\text { dengan penyedia jasa transportasi online } \\
\text { lainnya }\end{array}$ & 1 & 1 & 35 & 48 & 25 & 3,86 \\
\hline 2 & $\begin{array}{l}\text { Pelayanan yang diberikan Go-jek sesuai } \\
\text { dengan biaya yang saya bayarkan setelah } \\
\text { menggunakan Go-jek }\end{array}$ & 1 & 3 & 21 & 57 & 28 & 3,98 \\
\hline 3 & Kinerja Go-jek sesuai dengan harapan & 0 & 2 & 26 & 55 & 27 & 3,97 \\
\hline 4 & $\begin{array}{l}\text { Saya berminat untuk menggunakan } \\
\text { kembali jasa dari Go-jek }\end{array}$ & 0 & 3 & 18 & 52 & 37 & 4,11 \\
\hline & Total & & & & & & 3,98 \\
\hline
\end{tabular}

Sumber: Data diolah, 2018

Tabel 10.

Hasil Uji Normalitas

\begin{tabular}{llr}
\hline & & $\begin{array}{c}\text { Unstandardized } \\
\text { Residual }\end{array}$ \\
\hline $\mathrm{N}$ & & 110 \\
Normal Parameters a,b & Mean & .0000000 \\
& Std. Deviation & 1.86961319 \\
Most Extreme Differences & Absolute & .091 \\
& Positive & .047 \\
& Negative & -.091 \\
Kolmogorov-Smirnov Z & & .951 \\
Asymp. Sig. (2-tailed) & & .326 \\
\hline Sumber: Data diolah, 2018 & &
\end{tabular}

Tabel 11.

Hasil Uji Heteroskedastisitas

\begin{tabular}{clc}
\hline \multicolumn{1}{c}{ Persamaan } & \multicolumn{1}{c}{ Variabel } & Sig. \\
\hline $\mathrm{Y}=\mathrm{a}+\beta_{1} \mathrm{X}+\beta_{2} \mathrm{Z}+\beta_{3} \mathrm{X} Z \mathrm{Z}+\mathrm{e}$ & Kepuasan pelanggan $(\mathrm{X})$ & 0,164 \\
& Gender $(\mathrm{Z})$ & 0,236 \\
& Interaksi antara kepuasan pelanggan dengan & 0,208 \\
& Gender (X.Z) & \\
\hline
\end{tabular}

Sumber: Data diolah, 2018 
Tabel 12.

Hasil Uji Interaksi (Moderated Regression Analysis)

\begin{tabular}{lrrrrrr}
\hline Model & \multicolumn{3}{c}{$\begin{array}{c}\text { Unstandardized } \\
\text { Coefficients }\end{array}$} & $\begin{array}{c}\text { Standardized } \\
\text { Coefficients }\end{array}$ & & \\
\cline { 2 - 5 } & \multicolumn{1}{c}{ B } & Std. Error & Beta & \multicolumn{1}{c}{ T } & Sig. \\
& .035 & 1.752 & & .020 & .984 \\
1 (Constant) & .685 & .126 & .552 & 5.427 & .000 \\
Kepuasan pelanggan (X) & 2.652 & 1.033 & .426 & 2.568 & .012 \\
Gender (Z) & .164 & .058 & .493 & 2.840 & .005 \\
Interaksi antara kepuasan pelanggan & & & & & & 0,643 \\
dengan gender (XZ) & & & & & 0,633 \\
R Square & & & & & 63,596 \\
Adjusted R Square & & & & & 0,000 \\
F Hitung & & & & &
\end{tabular}

Sumber: Data diolah, 2018

Hasil analisis regresi moderasi seperti yang disajikan pada Tabel 12. maka persamaan strukturalnya adalah sebagai berikut:

$$
\begin{aligned}
& Y=\alpha+\beta_{1} X+\beta_{2} Z+\beta_{3} X Z+e \ldots \ldots \ldots \ldots \ldots \\
& Y=0,035+0,685 X+2,652 Z+0,164 X Z
\end{aligned}
$$

Persamaan regresi diatas memiliki makna operasional sebagai berikut. Nilai koefisien regresi $\left(\beta_{1}\right)=0,685$, berarti bahwa apabila variabel kepuasan pelanggan (X) meningkat, maka akan mengakibatkan peningkatan terhadap variabel loyalitas pelanggan (Y) dengan asumsi variabel bebas lainnya konstan, Nilai koefisien regresi $\left(\beta_{2}\right)=2,652$ berati apabila variabel gender $(Z)$ meningkat, maka akan mengakibatkan peningkatan pada loyalitas pelanggan $(\mathrm{Y})$ dengan asumsi variabel bebas lainnya konstan, Nilai koefisien regresi interaksi $\left(\beta_{3}\right)=0,164$ berarti apabila interaksi kepuasan pelanggan dengan gender (XZ) meningkat, maka akan mengakibatkan peningkatan pada loyalitas pelanggan $(Y)$ dengan asumsi variabel bebas lainnya konstan.

Nilai koefisien regresi $\beta_{3}$ signifikansinya $0,005<0,05$ (signifikan), berarti gender (Z) merupakan variabel moderasi, karena nilai koefisien regresi $\beta_{3}$ signifikan. $\beta_{1}$ positif dan $\beta_{3}$ positif signifikan, maka gender sebagai pemoderasi yang memperkuat pengaruh dari kepuasan pelanggan pada loyalitas pelanggan.

Tabel 13.

Hasil Uji Kesesuaian Model (Uji F)

\begin{tabular}{llccccc}
\hline & Model & Sum of Squares & Df & Mean Square & F & Sig. \\
\hline 1 & Regression & 685.768 & 3 & 228.589 & 63.596 & $.000^{\mathrm{a}}$ \\
& Residual & 381.004 & 106 & 3.594 & & \\
& Total & 1066.773 & 109 & & & \\
\hline
\end{tabular}

Sumber: Data diolah, 2018

Tabel 13. hasil dari uji $\mathrm{F}$ (Ftest) memperlihatkan signifikansi $\mathrm{F}_{\text {hitung }}$ sebesar $0,000<0,05$ maka $\mathrm{H}_{0}$ ditolak, ini berarti kepuasan pelanggan dan gender berpengaruh signifikan secara bersama - sama terhadap loyalitas pelanggan 
Tabel 14.

Hasil Uji Koefisien Determinasi $\left(\mathbf{R}^{2}\right)$

\begin{tabular}{ccccc}
\hline Model & R & R Square & Adjusted R Square & $\begin{array}{c}\text { Std. Error of the } \\
\text { Estimate }\end{array}$ \\
\hline 1 & $.802^{\mathrm{a}}$ & .643 & .633 & 1.89589 \\
\hline
\end{tabular}

Sumber: Data diolah, 2018

Hasil dari uji koefisien determinasi dalam Tabel 14. memperlihatkan besarnya nilai dari adjusted $\mathrm{R}^{2}$ yaitu sebesar 0,633. Ini mengartikan variasi loyalitas pelanggan dapat dipengaruhi secara signifikan oleh variabel kepuasan pelanggan, gender, dan variabel interaksi antara kepuasan pelanggan dengan gender sebesar 63,3 persen kemudian 36,7 persen sisanya dijelaskan oleh faktorfaktor lainnya.

Uji t dipakai untuk mengetahui apakah suatu variabel bebas secara individu dapat berpengaruh kepada variabel terikatnya. Hasil analisis pengaruh kepuasan pelanggan terhadap loyalitas pelanggan nilai signifikan thitung sebesar $0,000<0,05$ maka $\mathrm{H}_{0}$ ditolak, ini berarti kepuasan pelanggan berpengaruh signifikan terhadap loyalitas pelanggan. Hasil analisis regresi moderasi menunjukkan bahwa signifikan $\beta_{3}$ sebesar $0,005<0,05$ maka $\mathrm{H}_{0}$ ditolak, ini berarti gender memoderasi pengaruh kepuasan pelanggan terhadap loyalitas pelanggan. Hasil uji ditemukan bahwa $\beta_{1}$ positif dan $\beta_{3}$ positif signifikan, maka gender sebagai variabel moderasi yang memperkuat pengaruh kepuasan pelanggan terhadap loyalitas pelanggan PT. Go-jek Indonesia.

Berdasarkan hasil uji analisis moderasi, menunjukkan bahwa hasil analisis pengaruh kepuasan pelanggan terhadap loyalitas pelanggan diperoleh nilai signifikansi sebesar 0,000 dengan nilai koefisien beta 0,685 . Nilai signifikansi $0,000<(\alpha) 0,05$ mengindikasikan bahwa $\mathrm{H}_{0}$ ditolak dan $\mathrm{H}_{1}$ diterima. Hasil ini mempunyai arti bahwa kepuasan pelanggan berpengaruh positif dan signifikan terhadap loyalitas pelanggan pada PT. Go-Jek Indonesia. Dengan demikian, semakin meningkat kepusan pelanggan Go-jek, maka potensi tumbuhnya loyalitas pelanggan akan semakin meningkat, dan sebaliknya jika kepuasan pelanggan Gojek menurun, maka potensi terjadinya loyalitas pelanggan menurun.

Berdasarkan hasil uji analisis regresi moderasi menunjukkan pengaruh kepuasan pelanggan pada loyalitas pelanggan $\left(\beta_{1}\right)$ diperoleh nilai signifikansi sebesar 0,000 (significant) dengan nilai koefisien regresi sebesar 0,685. Nilai signifikansi variabel moderasi gender pada loyalitas pelanggan $\left(\beta_{2}\right)$ sebesar 0,012 (significant) dengan nilai koefisien beta sebesar 2,652 dan nilai signifikan variabel interaksi antara kepuasan pelanggan dengan gender pada loyalitas pelanggan $\left(\beta_{3}\right)$ sebesar 0,005 dengan nilai koefisien beta sebesar 0,164 (significant), hal ini mengindikasikan variabel moderasi merupakan tipe moderasi semu (quasi moderasi), karena koefisien $\left(\beta_{2}\right)$ significant dan koefisien $\left(\beta_{3}\right)$ significant. Quasi moderasi merupakan variabel yang memoderasi hubungan antara variabel dependen dan variabel independen di mana variabel moderasi semu berinteraksi dengan variabel dependen sekaligus menjadi variabel dependen. Hasil analisis regresi moderasi menunjukkan bahwa Nilai koefisien regresi $\beta_{3}$ signifikansinya $0,005<0,05$ (signifikan), berarti gender merupakan variabel moderasI. Hasil uji ditemukan bahwa $\beta_{1}$ positif dan $\beta_{3}$ positif signifikan, maka gender sebagai 
variabel moderasi yang memperkuat pengaruh kepuasan pelanggan terhadap loyalitas pelanggan PT. Go-jek Indonesia.

\section{SIMPULAN DAN SARAN}

Simpulan dari hasil penelitian yaitu kepuasan pelanggan berpengaruh positif dan signifikan terhadap loyalitas pelanggan, yang berarti semakin meningkat kepusan pelanggan, maka potensi tumbuhnya loyalitas pelanggan akan semakin meningkat. Gender memoderasi pengaruh kepuasan pelanggan terhadap loyalitas pelanggan, gender sebagai variabel moderasi yang memperkuat pengaruh kepuasan pelanggan terhadap loyalitas pelanggan PT. Go-jek Indonesia.

Terdapat beberapa keterbatasan dalam penelitian ini yaitu, ruang lingkup penelitian ini terbatas pada wilayah Kota Denpasar sehingga hasil penelitian ini tidak dapat di generalisasi untuk konsumen di luar wilayah Kota Denpasar serta jumlah responden yang dilibatkan juga terbilang masih kurang, Penelitian ini hanya dilakukan dalam jangka waktu tertentu (cross-section), sedangkan lingkungan dapat berubah setiap saat (dinamis) sehingga penelitian ini perlu dilakukan kembali di masa mendatang, selanjutnya terbatasnya referensi mengenai gender yang berhubungan dengan kepuasan pelanggan terhadap loyalitas pelanggan.

Saran yang dapat diberikan berdasarkan hasil penelitian adalah Pihak manajemen Go-jek harus meningkatkan kembali kepuasan pelanggan Go-jek karena berdasarkan penelitian, pernyataan mengenai kepuasan pelanggan secara keseluruhan Go-jek memiliki skor yang rendah. Oleh karena itu, pihak manajemen Go-jek dapat berupaya mengatasi hal tersebut dengan memperbaiki kualitas pelayanan dan aplikasi dari Go-jek, meningkatkan kinerja driver/pengemudi serta memberikan training kepada calon pengemudi ataupun yang sudah menjadi pengemudi Go-jek sehingga pengemudi Go-jek dapat memberikan pelayanan sesuai yang diinginkan oleh pelanggannya, membangun kepercayaan pada pelanggan, penangan keluhan yang baik dari pihak manajemen Go-jek dengan langsung menindaklanjuti keluhan-keluhan yang diutarakan oleh pelanggan dan memberikan solusi atas masalah yang dialami pelanggan yang berkaitan dengan jasa dari Go-jek.

Pihak manajemen Go-jek harus memperhatikan dan mengupayakan untuk meningkatkan loyalitas pelanggannya karena berdasarkan penelitian, pernyataan pelanggan tetap menggunakan layanan Go-jek sekalipun tersedia banyak layanan jasa transportasi online lainnya serta pernyataan bahwa Go-jek adalah penyedia jasa transportasi online yang terbaik memiliki skor yang rendah. Sebaiknya pihak manajemen Go-jek berupaya untuk terus melakukan inovasi dalam jasa yang ditawarkan, memberikan potongan harga khusus bagi pelanggan yang loyal, memperbaiki kualitas pelayanan, memberikan jaminan keamanan kepada pelanggannya, jaminan mendapatkan ganti rugi bila kualitas pelayanan tidak sesuai dengan yang dijanjikan, guna dapat meningkatkan loyalitas pelanggannya agar tidak terpengaruh oleh pesaing Go-jek yang lainnya.

Penelitian menunjukkan bahwa variabel gender berpengaruh positif signifikan, dan memperkuat pengaruh kepuasan pelanggan pada loyalitas 
pelanggan. Dalam hal ini pihak manajemen Go-jek dapat mempertimbangkan faktor tersebut sebagai ukuran dalam mengambil keputusan melayani pelanggan serta memenuhi kebutuhan pelanggannya. Hal itu dikarenakan variabel tersebut dapat dijadikan sebagai indikasi bagaimana tingkat kepuasan pelanggan berbeda jika dilihat dari aspek gender tergantung kebutuhan serta pertimbangan masing masing individu.

Dari hasil Adjusted $R$ square sebesar 63,3 persen menunjukkan bahwa masih terdapat variabel lain yang dapat memoderasi pengaruh kepuasan pelanggan terhadap loyalitas pelanggan seperti perbedaan karakteristik pelanggan yang mencakup usia dan pengetahuan serta manajemen nilai pelanggan. Diharapkan agar peneliti selanjutnya mempertimbangkan faktor lain tersebut sebagai acuan untuk dapat menyempurnakan penelitian ini.

\section{REFERENSI}

Anggarayana, D. P. G. W., \& Pramudana, K. A. S. (2013). Pengaruh Kualitas Layanan Terhadap Kepuasan Pelanggan dan Loyalitas Pelanggan Pada UD Dewa Putu Toris Gianyar. E-Jurnal Manajemen Universitas Udayana, 1346-1360.

Arwani, M., Zain, D., Surachman, \& Djumahir. (2011). ). Peran Karakteristik Individu Sebagai Moderator dan Pemasaran Relasional Sebagai Mediator Pengaruh Kepuasan Terhadap Loyalitas (Studi Pada Nasabah Bank Syariah Jawa Timur). Jurnal Aplikasi Manajemen, 9(3), 953-961.

Buttle, F. (2017). Custumer Relationship Management (Manajemen. Hubungan Pelanggan). Jakarta: Bayumedia.

Cahyana, M. A. D., \& Sukaatmadja, I. P. G. (2017). Pengaruh Retail Marketing Mix Terhadap Kepuasan Dan Loyalitas Pelanggan. E-Jurnal Manajemen Unud, 5(1), 975-1006.

Chang, N., \& Fong, C. (2010). Green Product Quality, Green Corporate Image, Green Customer Satisfaction and Green Customer Loyalty. African Journal of Business Management Vol., 4(13), 2836-2844.

Dhinata, D. M., \& Kusumadewi, N. M. W. (2014). Peran Gender dalam Memoderasi Pengaruh Kepuasan Pelanggan Terhadap Loyalitas Pelanggan Rama Krisna Oleh-Oleh Khas Bali. E-Jurnal Manajemen Universitas Udayana, 3(8), 2363-2377. Retrieved from https://ojs.unud.ac.id/index.php/Manajemen/article/view/8667

Dong, S., Ding, M., Grewal, R., \& Zhao, Y.-P. (2011). Functional Forms of The Satisfaction-Loyalty Relationship. International Journal of Reasearch in Marketing, 28(11), 28-50.

Dwipayana, B., \& Sulistyawati, E. (2018). Peran Kepuasan dalam Memediasi 
Pengaruh Kepercayaan Terhadap Niat Beli Ulang pada Go-Food Di Feb Unud. E-Jurnal Manajemen Unud, 7(10), 5197-5229. https://doi.org/10.24843/EJMUNUD.2018.v7.i10.p1

Fata, K. (2015). Pengaruh Harga, Citra Merek, Dan Fitur Terhadap Kepuasan pelanggan Serta Dampaknya Pada Loyalitas Merek (Studi Kasus Produk Handphone Samsung Di Banda Aceh). Jurnal Kebangsaan, 4(7), 40-46.

Foroughi, A., Buang, N. A., Senik, Z. C., \& Hajmisadeghi, R. S. (2013). Impulse Buying Behaviour and Moderating Role of Gender among Iranian Shoppers. Journal of Basic and Applied Scientific Research, 3(4), 760-769.

Ghozali, I. (2016). Aplikasi Analisis Multivariate (8th ed.). Semarang: Badan Penerbit Universitas Diponegoro.

Griffin, J. (2005). Customer Loyalty. (Erlangga, Ed.) (Revisi). Jakarta.

Ha, J., \& Jang, S. (2010). Perceived values, satisfaction, and behavioral intentions: The role of familiarity in Korean restaurants. International Journal of Hospitality Management, 29(1), 2-13. https://doi.org/10.1016/j.ijhm.2009.03.009

Hamda, W. (2017). Pengaruh Kualitas Layanan Terhadap Loyalitas Pelanggan Gojek. Universitas Muhammadiyah Surakarta.

Heung, V. C. S., \& Tianming, G. (2012). Influence of Restaurant Atmospherics On Patron Satisfaction And Behavioral Intention. International Journal of Hospitality Management, 31, hal: International Journal of Hospitality Management, 31(4), 1167-1177. https://doi.org/10.1016/j.ijhm.2012.02.004

Jahanshahi, A. A., Gashti, M. A. H., Mirdamadi, S. A., Nawaser, K., \& Khaksar, S. M. S. (2011). Study the Effects of Customer Service and Product Quality on Customer Satisfaction and Loyalty. International Journal of Humanities and Social Science, 1(7), 253-260.

Kitapci, O., Dortyol, I. T., Yaman, Z., \& Gulmez, M. (2013). The paths from service quality dimensions to customer loyalty: An application on supermarket customers. Management Research Review, 36(3), 239-255. https://doi.org/10.1108/01409171311306391

Kotler, P., \& Kervin, L. K. (2009). Manajemen Pemasaran (13th ed.). Jakarta: Erlangga.

Lee, H. S. (2013). Major Moderators Influencing the Relationships of Service Quality, Customer Satisfaction and Customer Loyalty. Asian Social Science, 9(2), 1-11. https://doi.org/10.5539/ass.v9n2p1

Liu, C.-C., Tseng, H.-C., Chuang, L., \& Huang, C.-M. (2012). A Study of the 
Impact of the e-CRM Perspective on Customer Satisfaction and Customer Loyalty-Exemplified by Bank Sinopac. Journal of Economics and Behavioral Studies, 4(8), 467-476.

Ma, E., Qu, H., \& Eliwa, R. A. (2015). Customer Loyalti with Fine Dining: The Moderating Role Of Gender. Journal of Hospitality Marketing \& Management, 23(5), 513-535. https://doi.org/10.1080/19368623.2013.835250

Masitha, M. A., \& Suprihhadi, H. (2014). Pengaruh Harga, Variasi Produk, Ketidakpuasan Konsumen dan Iklan Pesaing Terhadap Perpindahan Merek. Jurnal Ilmu \& Riset Manajemen, 3(1), 1-18.

Okoroafo, S. C., Koh, A. C., \& Gammoh, B. S. (2010). Gender Differences in Perceptions of the Marketing Stimuli of Family Owned Businesses ( FOBs ). International Journal of Marketing Studies, 2(1), 3-12.

Prasada, I. P. E. A., \& Ekawati, N. W. (2018). Peran Kepuasan Pelanggan Memediasi Pengaruh Persepsi Harga Terhadap Loyalitas Pelanggan. EJurnal Manajemen Unud, 7(10), 5284-5313. https://doi.org/10.24843/EJMUNUD.2018.v7.i10.p4 ISSN:

Pratama, A. H. (2015). Kilas Balik Perkembangan Ojek Online di Indonesia Sepanjang 2015. Tech in Asia. Retrieved from http://id/techinasiakilasbalikojek-online-2015

Qayyum, A., Khang, D. B., \& Krairit, D. (2013). An analysis of the antecedents of loyalty and the moderating role of customer demographics in an emerging mobile phone industry. International Journal of Emerging Markets, 8(4), 373-391. https://doi.org/10.1108/IJoEM-02-2011-0019

Rasyid, H. Al. (2017). Pengaruh Kualitas Layanan Dan Pemanfaatan Teknologi Terhadap Kepuasan Dan Loyalitas Pelanggan Go-Jek. Jurnal Ecodemica, 1(2), 210-223.

Razak, A., Palilati, A., Hajar, I., \& Madjid, R. (2016). Customer Income Role as Moderation Variable of Satisfaction Effect on Customer Loyalty in Bank Negara Indonesia ( Persero ), Tbk . In Southeast Sulawesi. The International Journal Of Engineering And Science (IJES), 5(3), 58-64.

Shahroudi, K., \& Naimi, S. S. (2015). The Impact of Brand Image on Customer Satisfaction and Loyalty Intention ( Case Study: Consumer of Hygiene Products ). International Journal of Engineering Innovation \& Research, $3(1)$.

Sugiyono. (2014). Metode Penelitian Bisnis (Pendekatan Kuantitatif, Kualitatif dan $R \& D)$. Bandung: Alfabeta. 
Supar, D. A. W. A., \& Suasana, I. G. A. K. G. (2017). Peran Kepuasan Pelanggan dalam Memediasi Pengaruh Customer Relationship Management Terhadap Loyalitas Pelanggan. E-Jurnal Manajemen Unud, 6(3), 1564-1591.

Tjahjaningsih, E., \& Yuliani, M. (2009). Analisis Kualitas Produk dan Citra Merk dalam Mempengaruhi Keputusan Pembelian dan Dampaknya Terhadap Loyalitas Merek HP Nokia. Jurnal Ilmiah Telaah Manajemen, 6(2), 104118. Retrieved from http://www.unisbank.ac.id/ojs/index.php/fe5/article/view/2074

Topbrand-award. (2018). Top Brand Award. Retrieved from http://www.topbrand-award.com/

Wardhana, R. E. (2016). Pengaruh Customer Experience Terhadap Loyalitas Pelanggan dengan Kepuasan Pelanggan Sebagai Variabel Interverning (Studi Pada Konsumen Mie Rampok Tahanan Surabaya). Jurnal Ilmu Manajemen, 4(3), 1-9.

Wikipedia. (2018). Top Brand Award. Id.Wikipedia.Org. Retrieved from https://id.wikipedia.org/wiki/Top_Brand_Award

Yaqin, A., \& Ilfitriah, A. M. (2014). Pengaruh Kualitas Pelayanan Terhadap Kepuasan dan Loyalitas Nasabah Bank Pengguna E-Banking di Surabaya. Journal of Business and Banking, 4(2), 245-260.

YLKI. (2017). Warta Konsumen: Transportasi Online Kawan Atau Lawan. Yayasan Lembaga Konsumen Indonesia. Retrieved from https://ylki.or.id/2017/07/warta-konsumen-transportasi-online-kawan-ataulawan/ 